\title{
Late Pleistocene subsistence in the Great Basin: Younger Dryas-aged faunal remains from the Botanical Lens, Paisley Cave 2, Oregon
}

\author{
Bryan Hockett $^{\mathrm{a}, *}$, Martin E. Adams ${ }^{\mathrm{b}}$, Patrick M. Lubinski ${ }^{\mathrm{c}}$, Virginia L. Butler ${ }^{\mathrm{d}}$, Dennis L. Jenkins ${ }^{\mathrm{e}}$ \\ a Bureau of Land Management, Nevada State Office, 1340 Financial Blvd., Reno, NV 89502, United States \\ b Paleoinsect Research, PO Box 17650, Portland, OR 97217, United States \\ c Department of Anthropology, Central Washington University, 400 E. University Way, Ellensburg, WA 98926, United States \\ d Department of Anthropology, Portland State University, Portland, OR 97207, United States \\ ' Museum of Natural and Cultural History 1224, University of Oregon, Eugene, OR 97403, United States
}

\section{Introduction}

Knowledge of Younger Dryas (ca. 12,900 to 11,600 cal. BP) settlement and subsistence patterns in the Great Basin of western North America has become increasingly detailed over the past decade (Goebel et al., 2011). The primary sites revealing these details are Bonneville Estates Rockshelter, located in eastern Nevada in the extreme western Bonneville Basin (Graf, 2007; Hockett, 2007, 2015), and the Paisley Caves, located in the Summer Lake Basin of south-central Oregon (Jenkins et al., 2012, 2013, 2016; Hockett and Jenkins, 2013). At Bonneville Estates Rockshelter, animal based subsistence centered upon the hunting and gathering of artiodactyls (pronghorn [Antilocapra americana], mountain sheep [Ovis canadensis], and mule deer [Odocoileus hemionus]), jackrabbits (Lepus sp.), sage grouse (Centrocercus urophasianus), and western long-winged katydids (Capnobotes occidentalis) (Hockett, 2015). At the Paisley Caves, preliminary reporting of the zooarchaeological remains recovered from a Younger Dryas-aged feature known as the Botanical Lens (BL) (Hockett and Jenkins, 2013) indicated that pronghorn, jackrabbits, sage grouse, fish, and perhaps marmots (Marmota flaviventris) and Mormon crickets (Anabrus simplex) were consumed. This paper adds to our growing understanding of Great Basin hunter-gatherer subsistence during the Younger Dryas by providing a detailed taphonomic examination of the faunal remains recovered from the BL feature at Paisley Cave 2.

\section{The Younger Dryas in the Great Basin}

Goebel et al. (2011) recently reviewed the climatic and biogeographic patterning of the Younger Dryas climatic event in the Great Basin, including what is known about human settlement and subsistence practices between 12,900 and 11,600 cal. BP. Briefly, the Younger Dryas in the Great Basin saw a return to cooler and wetter conditions following general reductions in Late Pleistocene lake levels beginning between 16,000 and 17,000 cal. BP. Marshes were prevalent across much of the Great Basin. The availability of a diverse suite of plant and animal resources fostered the beginnings of a human population pulse, as improving ecological conditions may have expanded the availability of populations of artiodactyls, rabbits, fish, waterfowl, sage grouse, insects, and seed and root crops known to be human dietary items during the late Pleistocene/early Holocene (Hockett and Jenkins, 2013; Hockett, 2015). Bifacial technology centered on the production of Western Stemmed Tradition (WST) projectile points and knives, along with a variety of scrapers, gravers, and chopping tools. A welldeveloped suite of textiles including basketry, sandals, cordage, sewing threads, and rope were produced. Tiny eyed bone needles and bone awls have been recovered at several Great Basin sites including Bonneville Estates Rockshelter, Cougar Mountain Cave, and Connley Cave 4 (Goebel et al., 2011:488, Fig. 10). Personal ornamentation is indicated by the presence of bone bead manufacturing blanks at Bonneville Estates Rockshelter, sinew wrapped feather quills at Paisley Cave 2, and an incised deer incisor at Connley Cave 4. This 'explosion' of material culture likely indicates in situ development from huntergatherer populations who occupied the region prior to the Younger Dryas (Jenkins et al., 2012, 2013).

Although WST projectile points are common across the Great Basin, very few sites in the region have been reliably dated. Goebel et al. (2011) identified 10 Great Basin sites reliably dated to the Younger Dryas chronozone. WST points were manufactured for at least 4000 years (ca. 13,000 to $9000 \mathrm{cal}$. BP), and perhaps much longer as suggested by early dates (ca. 14,000-14,500 cal. BP) from the Paisley Caves (Jenkins et al., 2012). WST points were eventually replaced by foliate and large side-notched points sometime during the latter early Holocene to early Middle Holocene (Jenkins et al., 2004:8). While this transition is not generally well dated, and the timing was likely variable across the Basin, it likely dates between 7500 and 8500 cal. BP in many areas. WST points are found almost everywhere Younger Dryas-aged lakes and marshes existed, including large watershed basins such as Bonneville and Lahontan, as well as numerous smaller upland lakes and

\footnotetext{
* Corresponding author.

E-mail addresses: b50hocke@blm.gov (B. Hockett), paleoinsect@gmail.com (M.E. Adams), lubinski@cwu.edu (P.M. Lubinski), Virginia@pdx.edu (V.L. Butler), djenkins@uoregon.edu (D.L. Jenkins).
} 


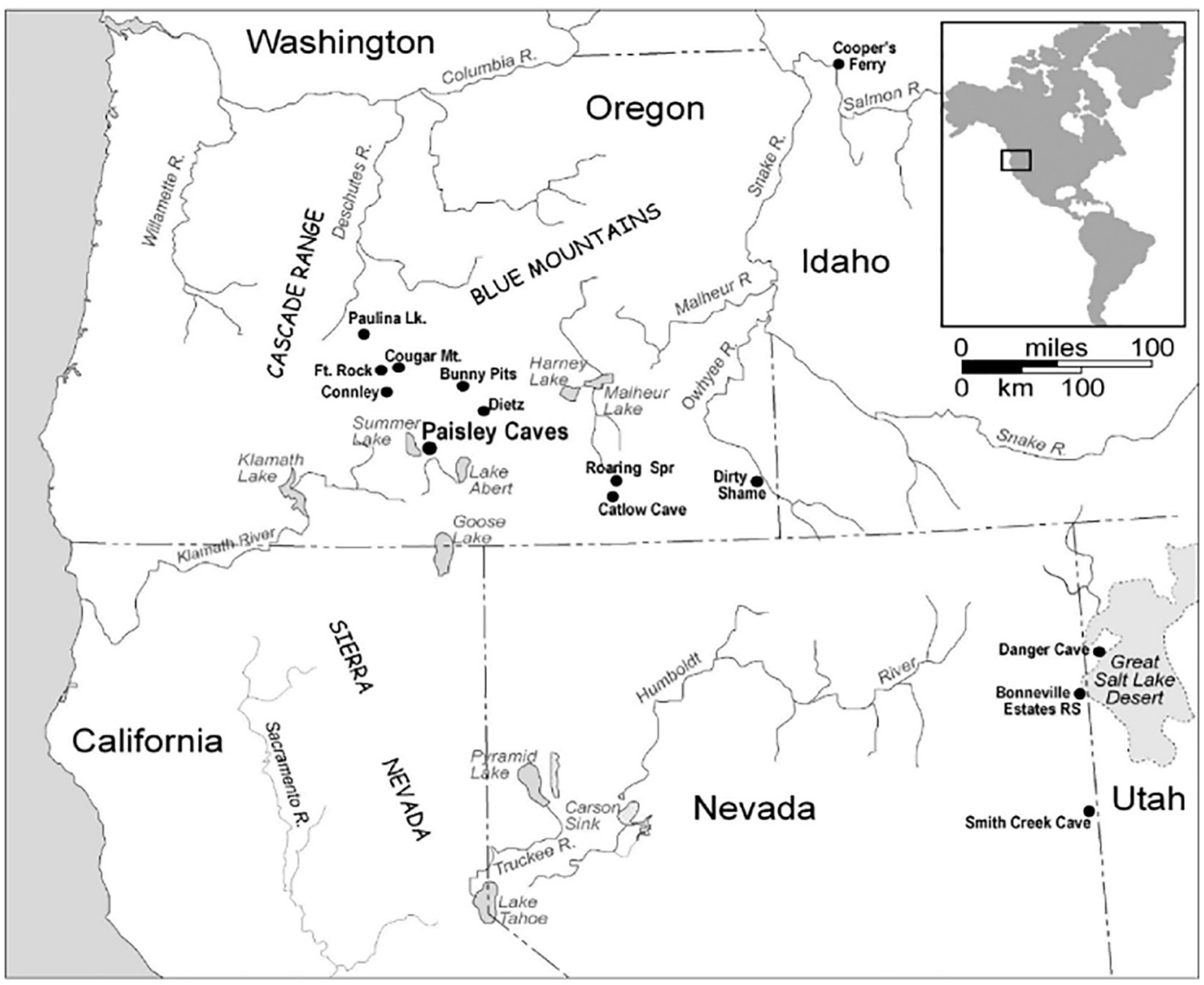

Fig. 1. Location of Paisley Caves and other important WST sites in the northern Great Basin (after Jenkins et al., 2013).

springs, indicating that while hunter-gatherers certainly spent considerable time near lowland lakes and marshes, upland forays to elevations between 8000 and $11,000 \mathrm{ft}$ were not eschewed. In fact, this is the reason the 'Western Pluvial Lakes Tradition' concept, which drew too much attention away from sites that are not in lowland lacustrine settings, has been supplanted in recent years with the more generic 'Western Stemmed Tradition' (WST) which embraces diagnostic technological attributes while eliminating the restrictive ecological correlates associated with lakes and marshes (Jenkins et al., 2016:129).

\section{Description of the Botanical Lens at Paisley Cave 2}

The paleoenvironmental context of the Paisley Caves, the Cave 2 stratigraphy, and the formation of the BL within Cave 2 are briefly discussed below to provide site context to the faunal analysis that follows.

\subsection{Paleoenvironmental context of the Paisley Caves}

The Paisley Caves are in a west-facing Miocene basalt and rhyolite ridge in the Summer Lake basin of south-central Oregon (Fig. 1). The Summer Lake basin is the northernmost sub-basin of the Chewaucan hydrologic system. It is separated from the Lower Chewaucan basin by a broad gravel fan formed at the mouth of the Chewaucan River at Paisley. At the end of the Late Glacial Maximum (ca. 22,000-21,000 cal. BP), as Lake Chewaucan receded from its high stand, the river entrenched south of the fan and flowed into ZX Lake in the Upper Chewaucan Marsh (Freidel, 2001). North of the fan, Pleistocene Winter Lake was cut off from its primary water source and receded rapidly. About 14,700 cal. BP an increase in local precipitation and reduction in evaporation caused a rise in ZX Lake levels, water overtopped the gravel fan, and a river began flowing north into the
Summer Lake basin, cutting a channel across the plain to within $1.6 \mathrm{~km}$ of the Paisley Caves. Faunal remains from Paisley Caves indicate that the plain, the river's delta marsh, and grasslands surrounding the rejuvenated lake provided improved pasturage for proboscidians (mammoth [Mammuthus] and mastodon [Mammut]), camelids (Yesterday's camel [Camelops] and large-headed llama [Hemiauchenia]), horse (Equus spp.), bison (Bison), deer (Odocoileus), elk or North American red deer (Cervus), and pronghorn (Antilocapra) (Hockett and Jenkins, 2013). Mountain sheep (Ovis canadensis), marmots (Marmota), and upland root plants were likely available in the hills east of the plain. By $13,000 \mathrm{cal}$. BP, due to changing ecological conditions and perhaps increased human predation, Rancholabrean megafauna were locally extinct from the region, or rapidly becoming so (Grayson, 2016).

\subsection{General stratigraphy of Paisley Cave 2 and the stratigraphic position of the Botanical Lens}

Paisley Cave 2 is seven meters long and six meters deep from dripline to back wall (Fig. 2). A massive roof-fall extends across most of the entrance, blocking direct access to the central and southern portions of the cave. The triangular scar from which the roof fall was dislodged remains discernible above the mouth of the cave. Prior to the roof fall sometime after ca. 2000 cal. BP, Cave 2 was open to direct entry but was darker than it is today. University of Oregon field school excavations between 2002 and 2011 covered a total of $22 \mathrm{~m}^{2}$ and removed $30.3 \mathrm{~m}^{3}$ of sediments from Cave 2 (Jenkins et al., 2016).

Four broad stratigraphic units (LU1-LU4) and one prominent stratigraphic cultural feature (Botanical Lens) were identified in the excavations of Cave 2 (Fig. 3). Stratum LU1 is a culturally sterile sandy gray gravel surrounding wave-rounded boulders and cobbles on the cave floor to varying depths above bedrock. It is the floor of the cave left by receding Lake Chewaucan ca. 19,000-18,000 cal. BP. Stratum 


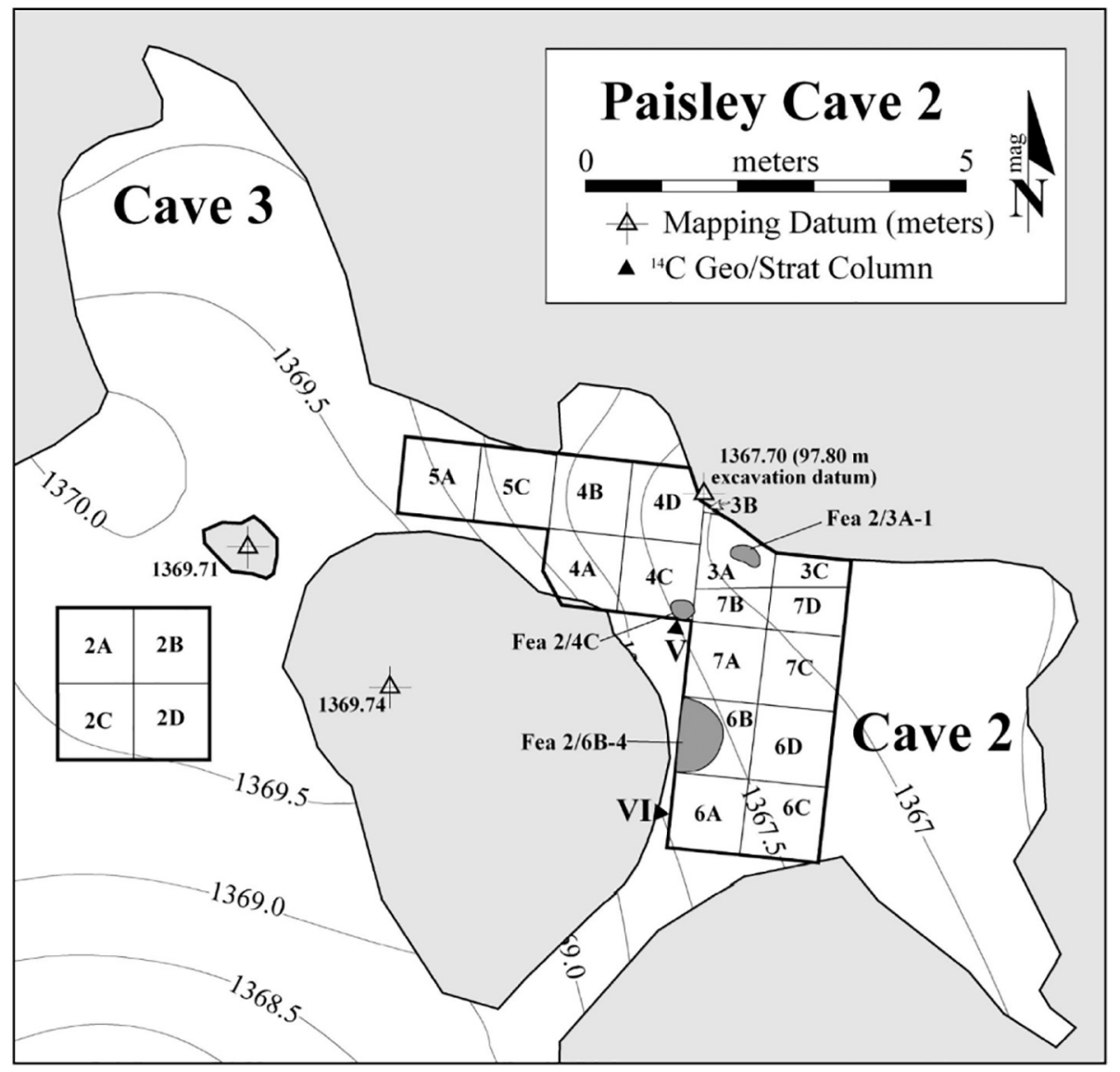

Fig. 2. Plan view map of Paisley Cave 2 with locations of units excavated (after Jenkins et al., 2013).

LU2, overlying LU1, is a 15-30 cm thick layer of brown gravelly sand, dating between ca. 14,700 and 12,900 cal. BP. LU2 is capped in places by a thin (ca. 1-3 cm) alluvial silt lens-the Lower Mud-laid down ca. $12,900 \mathrm{cal}$. BP $\left(11,000{ }^{14} \mathrm{C}\right.$ yr BP), marking the beginning of the Younger Dryas chronozone in the northwestern Great Basin. Because the Paisley Caves face into the predominant southwest wind and were formed by pluvial lake wave action, sporadic and intense storms occasionally resulted in rainwater reaching into the cave. This moisture accumulated and briefly flowed toward the mouth of the cave producing thin (ca. 1-3 cm) silt lenses which cracked as they dried, forming the Lower Mud in LU2.

The Lower Mud is overlain by the BL, a distinctive cultural feature that consists of a mat of sagebrush twigs and shredded bark some 5-8 cm thick, clearly of human origin, and two thermal features as well. The Upper Mud capping the BL formed about 11,500 cal. BP $\left(10,000{ }^{14} \mathrm{C}\right.$ yr BP). The BL, then, is capped above and below by fine silt layers representing these increased moisture events.

Stratum LU3 is a $90 \mathrm{~cm}$ thick, compact deposit of bat guano overlying the Upper Mud. It continues to the base of LU4, the laminated Mt. Mazama tephra dated at ca. $7640 \mathrm{cal}$. BP $\left(6800{ }^{14} \mathrm{C}\right.$ yr BP $)$. Limited lithic debitage between the BL and the Mt. Mazama tephra indicates occupations were infrequent and very brief. However, just prior to the Mt. Mazama eruption, people began to use the cave more frequently and apparently as part of small-seed collection forays, based on increased frequency of ground stone (metates and manos) and basketry.

\subsection{General description and origin of the Botanical Lens}

Multiple lines of evidence suggest the BL was deposited primarily by human activities. This dense cultural deposit was easily recognizable during excavation by its unique characteristics including a high abundance of botanical remains (e.g., shredded sagebrush [Artemisia tridentata] bark), presence of relatively dense lithic tools and obsidian debitage compared to the surrounding units, smashed, split, and stonetool cut pronghorn bones, masses of white pronghorn underbelly hair with straight cuts indicating it was shaved from the hide by human occupants (Fig. 4), rabbit hair and hide, charcoal fragments, cordage made primarily of sagebrush bark, and two unlined hearths. The sagebrush mat was laid down by human occupants presumably to reduce dust and provide a cleaner living surface on which to process and consume meals.

The BL was usually encountered horizontally across four two meter $\times$ two meter excavation units (Units 3, 4, 6, and 7; see Fig. 2), and was excavated in 14 one meter $\times$ one meter subunits within these four units (Subunits 3A, 3B, 3C, 4A, 4C, 4D, 6A, 6B, 6C, 6D, 7A, 7B, 7C, and 7D). Vertically, it averaged three to four five-cm excavation levels $(15-20 \mathrm{~cm}$ in depth) when the mud lenses were not present, indicating some foot traffic admixture on the cave floor in those areas. The BL is well dated by 19 AMS dates on macrobotanical remains, charcoal recovered from intact hearths, cordage, wood artifacts, artiodactyl bone and hair, human hair, and human coprolites ranging between 12,810 and 10,950 cal. yr BP. However, fully $74 \%$ (14 of 19) of all dates overlap between about 12,000 and 12,200 cal. yr BP suggesting the BL was primarily utilized by humans for up to two centuries before it was abandoned and later buried by the Upper Mud Lens. For additional details of the Paisley Caves stratigraphic context, including the Botanical Lens, see Jenkins et al. (2016).

\subsection{Botanical Lens taphonomy and samples included in analysis}

As noted above, the BL represents a Younger Dryas aged cultural feature discovered during excavations of Paisley Cave 2. The human occupants of the cave laid down a bed or mat of shredded sagebrush bark, presumably to reduce dusty conditions and to provide a cleaner 


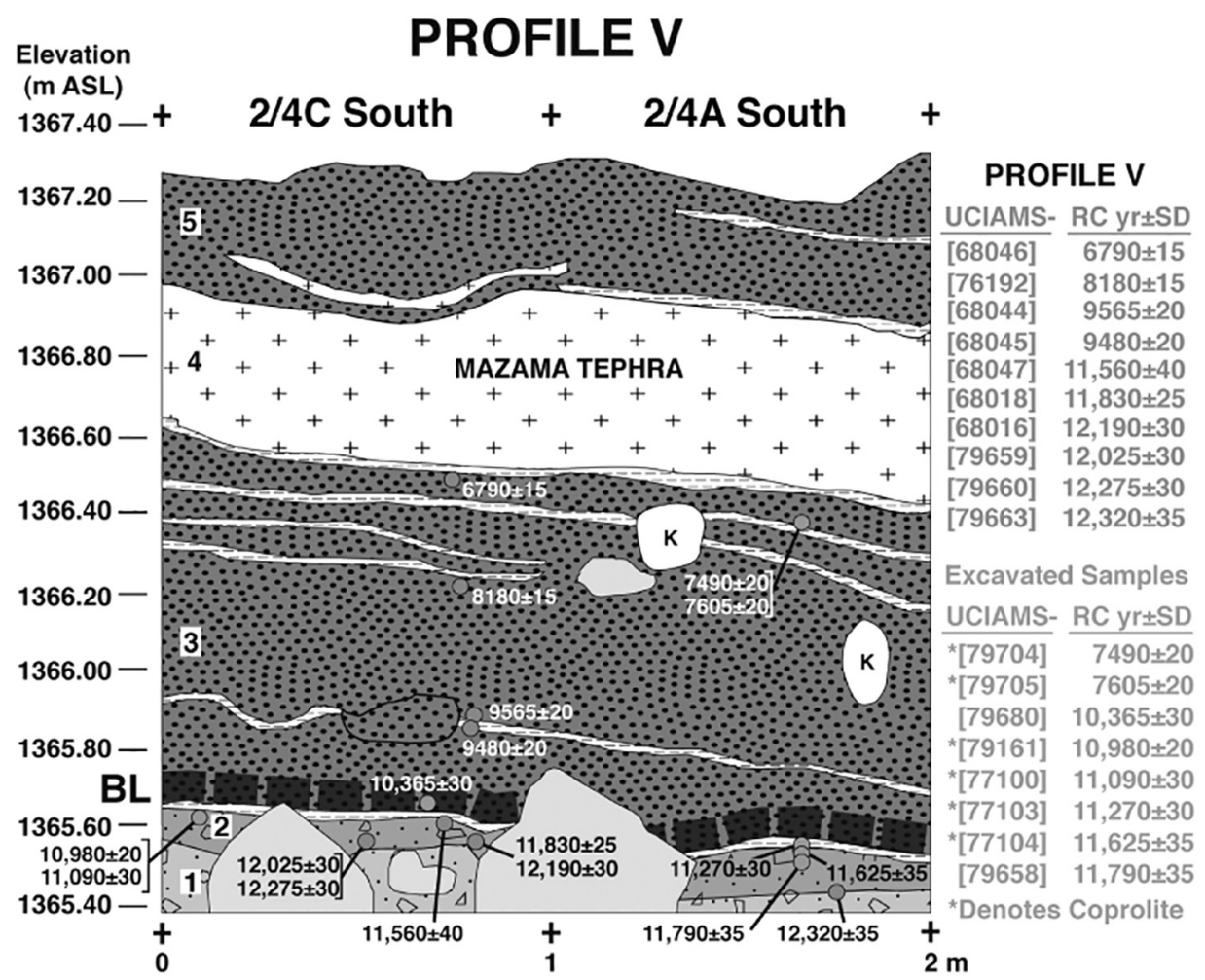

Poorly sorted angular gravelly sand with trace organic content [LU1]

Poorly sorted angular gravelly sandy loam with trace to common macrobotanical content, common Chiroptera sp. and Neotoma sp. feces and common amorphous organics [LU2]

Firm to hard fine sediments with abundant macrobotanical and trace to common gravel content, abundant to very abundant Chiroptera sp. and Neotoma sp. feces and amorphous organics [LU3, 5]

\begin{tabular}{|l|l|}
\hline Key to Figure \\
++ & Mazama tephra and lapilli [LU4] \\
+ & Silty sediments \\
K $\quad$ Krotovina & Cobble to boulder-sized rocks \\
BL $\quad$ Botanical Lens
\end{tabular}

Fig. 3. Stratigraphic position of the Botanical Lens (BL) within Cave 2 (after Jenkins et al., 2013).

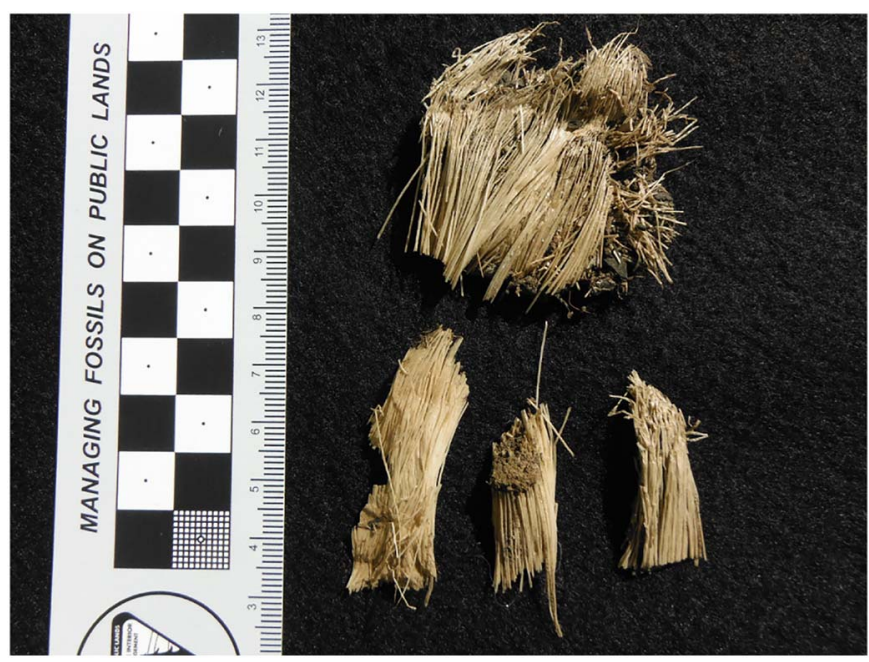

Fig. 4. Samples of cut pronghorn hair recovered from the Botanical Lens. living surface with which to process animal remains collected while using the cave as a campsite, as well as to use the bark in the manufacturing of string and rope. Higher moisture penetration inside the cave both before and after this occupation or series of occupations (the Lower Mud and Upper Mud, respectively), sealed and helped preserve the BL in a relatively intact condition, especially given its antiquity.

Nevertheless, the BL was not sealed overnight, and some intrusions occurred, particularly along its lateral margins. These intrusions likely occurred from four primary sources: (1) human foot traffic inside and outside the BL feature while it was in use; (2) woodrats (Neotoma) carrying sticks, other vegetation and bones to and from their nests located inside the cave, which created midden deposits on various portions of the cave floor; (3) noncultural bone deposition through natural deaths, as well as deposition by carnivores and raptors via scats and pellets; these latter animals probably used the cave at sporadic times while the BL was accumulating and between the time the BL was abandoned and it was sealed by the Upper Mud Lens; and finally (4) intrusions from rodent burrowing activities.

Overall, the dates obtained from the BL indicate that most organic remains associated with the feature are in situ, and date to the Younger Dryas. In addition, many bones recovered from the BL are very well 
preserved, as are the insect remains associated with cultural activity (see below). This suggests that these organic remains were not exposed for an extended period prior to burial. Further, many bones from the BL were of similar color (light to golden brown) with minimal weathering.

However, some of the bags of faunal remains collected from the units associated with the BL were clearly of mixed origin, and some bones showed no apparent signs of cultural modification. Bags of faunal remains were examined for the presence of 10 or more bleached white bones; bags that fit this criterion consisted almost exclusively of bleached Rodentia bones, suggesting that rodent burrowing had penetrated portions of the BL feature and mixed bones with the Younger Dryas deposits. Other bags were noted by the excavators as intrusions of woodrat midden or bat guano. These bags and all their organic contents were simply removed in their entirety from this analysis.

In addition, detailed examination of the rodent, songbird, and carnivore bones from the 14 subunits of the BL demonstrated that none of these bones displayed cut marks or burning, and thus no indication of human involvement, further suggesting deposition in scats, pellets, or natural deaths. There were 114 rodent and 87 small songbird-sized bones recovered from the entire 14 subunits; these, too, were eliminated from our detailed analysis below.

The remaining bags recovered from the excavation of the 14 subunits of the BL contained faunal remains consistent in color and weathering; additionally, they contained culturally modified (stone tool cut and burned) mammal bones (pronghorn/artiodactyl, jackrabbit, and cottontail), as well as varying amounts of other faunal remains potentially deposited by human subsistence activities, including sage grouse bones, fish bones and scales, and insect remains. Detailed examination of these faunal remains identified from the 14 subunits of the BL is presented in the following section.

\section{Detailed examination of the Botanical Lens faunal remains}

The analysis of faunal remains recovered from the BL is divided into three parts: (1) mammals and sage grouse; (2) fish; and (3) arachnids and insects. Mammalian remains the size of rabbits and larger, and grouse remains were identified by Hockett by comparison to samples from the author's comparative collection. Fish bones were identified by Lubinski and Butler by comparison to voucher skeletons at Portland State University and Central Washington University, while scales were identified following the criteria provided by Casteel (1973). Arachnid and insect remains were identified by Adams by comparison to voucher specimens from the author's personal comparative collection. Taxonomic abundance was measured using both number of identified specimens (NISP; Payne, 1972) and minimum number of individuals (MNI; White, 1953) counts. MNI estimates relied on repeating element portions only, and did not use size or visual comparisons.

A summary of all identified remains from the BL sample is provided in Table 1, and a more detailed count of the NISP and MNI numbers for each identified taxon is presented in Table 2. Spatial examination of the faunal remains interpreted as human subsistence items indicated that they were not evenly distributed across these 14 subunits. As a group, many culturally modified (stone tool cut and burned) mammal remains, as well as relatively large numbers of sage grouse, fish, and insect remains, were recovered from seven of the 14 subunits: $4 \mathrm{~A}, 6 \mathrm{~A}, 6 \mathrm{~B}, 6 \mathrm{D}$, 7A, 7C, and 7D. The distribution of the faunal remains from these seven subunits are displayed in Table 3. Following a descriptive taphonomic analysis of each of the three categories of faunal remains, a summary and brief comparison of these data to those recently reported from Bonneville Estates Rockshelter and other late Pleistocene-early Holocene Great Basin sites is presented.

\subsection{Botanical Lens mammals and sage grouse}

A total of 479 pronghorn, artiodactyl, leporid (hare and cottontail)
Table 1

Summary of order-level faunal identifications from all the Botanical Lens subunits, Paisley Cave 2, Oregon.

\begin{tabular}{|c|c|c|}
\hline & NISP & $\%$ of assemblage \\
\hline \multicolumn{3}{|l|}{ Class Mammalia } \\
\hline Lagomorpha & 185 & 10 \\
\hline Artiodactyla & 268 & 14 \\
\hline Subtotal & 453 & 24 \\
\hline \multicolumn{3}{|l|}{ Class Aves } \\
\hline Galliformes & 26 & 1 \\
\hline Subtotal & 26 & 1 \\
\hline \multicolumn{3}{|c|}{ Class Actinopterygii } \\
\hline Salmoniformes & 26 & 1 \\
\hline Cypriniformes & 215 & 11 \\
\hline Indeterminate & 60 & 3 \\
\hline Subtotal & 301 & 15 \\
\hline \multicolumn{3}{|l|}{ Class Arachnida } \\
\hline Scorpiones & 5 & $<1$ \\
\hline Subtotal & 5 & $<1$ \\
\hline \multicolumn{3}{|l|}{ Class Insecta } \\
\hline Orthoptera & 162 & 8 \\
\hline Hemiptera & 18 & 1 \\
\hline Coleoptera & 268 & 14 \\
\hline Hymenoptera & 8 & $<1$ \\
\hline Lepidoptera & 54 & 3 \\
\hline Diptera & 603 & 31 \\
\hline Indeterminate & 34 & 2 \\
\hline Subtotal & 1147 & 59 \\
\hline Totals & 1932 & 100 \\
\hline
\end{tabular}

and sage grouse bones was identified from the BL (Tables 1 and 2). Of these, 224 (47\%) were identified to at least the genus level. Pronghorn and jackrabbit/hare dominate the mammalian faction. Taphonomic examination of these bones indicate that the clear majority were deposited by humans.

Because all the identifiable artiodactyl bones were pronghorn, the shaft fragments identified as 'artiodactyl' most likely derive from pronghorn as well; the size and shape of shaft fragments are consistent with a small artiodactyl such as pronghorn. Moreover, the 268 pronghorn and artiodactyl bones appear to be the remains of one individual. Almost $19 \%$ of the 268 bones identified as pronghorn/artiodactyl displayed cut marks, and $56 \%$ of them were burned (Tables 4 and 5; Fig. 5). None of them showed signs of carnivore gnawing or digestive corrosion. All parts of the pronghorn skeleton are represented (Table 4). Spatially, the pronghorn/artiodactyl bones were highly localized. While pronghorn/artiodactyl bones were found in each of the 14 subunits that made up the BL, if these bones were evenly distributed across these subunits then 19 bones or $7 \%$ of them should have been identified from each subunit. In fact, 91 (34\%) pronghorn/artiodactyl bones were recovered from two one meter $\times$ one meter blocks: subunits 7A (43 bones) and 7C (48 bones) (Table 3 ). If the remains were evenly dispersed, just $38(14 \%)$ pronghorn/artiodactyl bones should have been recovered from these two subunits. The overall picture to emerge is that hunters dispatched a single pronghorn near Cave 2, carried the whole carcass to the cave, then butchered and cooked it atop the shredded sagebrush bark that made up the BL feature.

The 153 identified jackrabbit bones represent the remains of at least seven hares (Table 2). The jackrabbit bones consisted of 20 distinctive long bone diaphysis cylinders created by humans snapping or biting off the proximal and distal ends to remove marrow (Hockett, 1991; Fig. 6). In addition, two hare bones displayed stone tool cutmarks, and $7 \%$ of them were burned (Tables 4 and 5). No hare bones exhibited adhering pellet material suggesting deposition by raptors. Only seven of the 153 (0.04) hare bones displayed evidence of noncultural deposition in the form of punctures and digestive corrosion. These seven bones were recovered from subunits $3 \mathrm{~A}$ and $4 \mathrm{~A}$, six of which were found in subunit 4A. While subunit $4 \mathrm{~A}$ is one of the seven that formed the detailed 
Table 2

Faunal remains identified from all the Botanical Lens subunits in Paisley Cave 2, Oregon.

\begin{tabular}{|c|c|c|}
\hline Taxon & NISP & MNI \\
\hline \multicolumn{3}{|l|}{ Mammals } \\
\hline Antilocapra americana (Pronghorn) & 34 & 1 \\
\hline Artiodactyla (Even-Toed Ungulates) & 234 & - \\
\hline Lepus spp. (Jackrabbit/Hare) & 153 & 7 \\
\hline Sylvilagus spp. (Cottontail) & 11 & 1 \\
\hline Leporidae (Rabbits) & 21 & - \\
\hline \multicolumn{3}{|l|}{ Birds } \\
\hline Centrocercus urophasianus (Sage Grouse) & 26 & 1 \\
\hline \multicolumn{3}{|l|}{ Fish } \\
\hline Actinopterygii (Unidentified Fish) & 60 & - \\
\hline Oncorhynchus sp. (Trout) & 26 & 1 \\
\hline Cypriniformes (Minnows, Suckers) & 175 & 5 \\
\hline Cyprinidae (Minnows) & 35 & - \\
\hline Siphateles bicolor (Tui Chub) & 5 & - \\
\hline \multicolumn{3}{|l|}{ Arachnids } \\
\hline \multicolumn{3}{|l|}{ Scorpiones (Scorpions) } \\
\hline Vaejovidae & 3 & 2 \\
\hline Indeterminate & 2 & 2 \\
\hline \multicolumn{3}{|l|}{ Insects } \\
\hline \multicolumn{3}{|l|}{ Orthoptera (Grasshoppers, Crickets, Katydids) } \\
\hline Stenopelmatidae (Jerusalem Crickets) & 52 & 35 \\
\hline Tettigoniidae (Katydids) & 107 & 18 \\
\hline Indeterminate & 3 & 2 \\
\hline \multicolumn{3}{|l|}{ Hemiptera (True Bugs) } \\
\hline Pentatomidae (Stink Bugs) & 13 & 8 \\
\hline Lygaeidae (Seed Bugs) & 2 & 2 \\
\hline Indeterminate & 3 & 1 \\
\hline \multicolumn{3}{|l|}{ Coleoptera (Beetles) } \\
\hline Carabidae (Ground Beetles) & 12 & 1 \\
\hline Histeridae (Clown Beetles) & 17 & 1 \\
\hline Dermestidae (Skin Beetles) & 128 & 40 \\
\hline Tenebrionidae (Darkling Beetles) & 100 & 29 \\
\hline Indeterminate & 11 & 8 \\
\hline \multicolumn{3}{|l|}{ Hymenoptera (Wasps, Bees, Ants) } \\
\hline Chrysididae (Cuckoo Wasps) & 4 & 1 \\
\hline Formicidae (Ants) & 1 & 1 \\
\hline Vespidae (Yellowjackets, Paper Wasps) & 1 & 1 \\
\hline Indeterminate & 2 & 2 \\
\hline \multicolumn{3}{|l|}{ Lepidoptera (Moths, Butterflies) } \\
\hline Noctuidae (Owlet Moths) & 6 & 4 \\
\hline Indeterminate & 48 & 28 \\
\hline \multicolumn{3}{|l|}{ Diptera (Flies) } \\
\hline Tabanidae (Deer/Horse Flies) & 7 & 2 \\
\hline Calliphoridae (Blow Flies) & 509 & 216 \\
\hline Oestridae (Bot Flies) & 8 & 2 \\
\hline Indeterminate & 79 & 27 \\
\hline Indeterminate Insects & 34 & 13 \\
\hline Totals & 1932 & 462 \\
\hline
\end{tabular}

spatial analysis presented here, this subunit overall contained low numbers of pronghorn, artiodactyl, hare, fish, and insect remains (Table 3). In contrast, 14 of the $20(70 \%)$ jackrabbit long bone diaphysis cylinders were recovered from six of the seven subunits identified in Table 3 other than 4A. During the Younger Dryas occupation of the BL, mammal hunting and butchery inside Paisley Cave 2 focused on pronghorn and jackrabbit, with seven hares and one pronghorn processed.

The sage grouse bones are somewhat enigmatic in that none of them displayed stone tool cutmarks or were burned. This contrasts with those recovered from Bonneville Estates Rockshelter, where many of the sage grouse bones were cut or burned during the butchering and cooking process prior to consumption (Hockett, 2007, 2015). Unfortunately, in the absence of either cut marks or burning, these bones cannot be confidently attributed to human hunting. On the other hand, a lack of carnivore or raptor tooth or beak/talon puncture marks and digestive damage leave open the possibility that sage grouse hunting by humans occurred near Cave 2.

Taking a closer look at the spatial patterning of the BL pronghorn,
Table 3

Spatial distribution of mammal, fish, and insect remains based on number of identified specimens (NISP) for 7 of the 14 excavation subunits, Botanical Lens, Paisley Cave 2.

\begin{tabular}{|c|c|c|c|c|c|c|c|c|}
\hline \multirow[t]{2}{*}{ Animal } & \multicolumn{8}{|c|}{ Excavation unit } \\
\hline & $2 / 4 \mathrm{~A}$ & $2 / 6 \mathrm{~A}$ & $2 / 6 \mathrm{~B}$ & $2 / 6 \mathrm{D}$ & $2 / 7 \mathrm{~A}$ & $2 / 7 \mathrm{C}$ & $2 / 7 \mathrm{D}$ & Totals \\
\hline Artiodactyls & 27 & 3 & 13 & 9 & 43 & 48 & 15 & 158 \\
\hline Jackrabbits & 20 & 1 & 7 & & 15 & 58 & 6 & 107 \\
\hline Sage Grouse & 5 & & 2 & & 1 & 6 & 2 & 16 \\
\hline Trout & 3 & 6 & 4 & 2 & & & 8 & 23 \\
\hline Minnows $^{\mathrm{a}}$ & 10 & 28 & 41 & 33 & 4 & 1 & 38 & 155 \\
\hline Scorpions & 1 & & & 1 & 1 & & & 5 \\
\hline Jerusalem Crickets & & 13 & 25 & 8 & & 1 & 4 & 51 \\
\hline Mormon Crickets & 1 & 2 & 101 & & 3 & & & 107 \\
\hline Stink Bugs & & 5 & 1 & & 3 & & 1 & 10 \\
\hline Seed Bugs & & & 1 & & & & 1 & 2 \\
\hline Ground Beetles & & 12 & & & & & & 12 \\
\hline Clown Beetles & & 17 & & & & & & 17 \\
\hline $\begin{array}{l}\text { Skin (Dermestid) } \\
\text { Beetles }\end{array}$ & & & & & & 128 & & 128 \\
\hline Darkling Beetles & 5 & 5 & 31 & 6 & 3 & 4 & 6 & 60 \\
\hline Cuckoo Wasps & & & 4 & & & & & 4 \\
\hline Yellowjackets & & 2 & & 1 & & & & 1 \\
\hline Owlet Moths & 4 & 11 & 4 & 11 & 2 & 3 & 1 & 2 \\
\hline Blow Flies & & 135 & 123 & 55 & 16 & 153 & 27 & 509 \\
\hline Bot Flies & & 7 & 1 & & & & & 8 \\
\hline Totals & 60 & 214 & 312 & 91 & 83 & 390 & 58 & 1375 \\
\hline
\end{tabular}

${ }^{\text {a }}$ Siphateles bicolor, Family Cyprinidae, and order Cypriniformes combined.

Table 4

Number of identified specimens of cut and burned pronghorn and hare bones recovered from the Botanical Lens, Paisley Cave 2, Oregon.

\begin{tabular}{|c|c|c|c|c|c|c|}
\hline \multirow[t]{2}{*}{ Element } & \multicolumn{3}{|c|}{ Pronghorn } & \multicolumn{3}{|l|}{ Hare } \\
\hline & NISP & Cut & Burned & NISP & Cut & Burned \\
\hline Skull fragment & 0 & 0 & 0 & 3 & 0 & 0 \\
\hline Mandible & 1 & 1 & 1 & 9 & 0 & 0 \\
\hline Maxilla & 1 & 1 & 0 & 3 & 0 & 0 \\
\hline Tooth & 2 & 0 & 0 & 12 & 0 & 0 \\
\hline Vertebra & 0 & 0 & 0 & 12 & 0 & 0 \\
\hline Innominate & 3 & 1 & 0 & 7 & 0 & 2 \\
\hline Sacrum & 0 & 0 & 0 & 1 & 0 & 0 \\
\hline Rib & 1 & 1 & 0 & 2 & 0 & 0 \\
\hline Scapula & 2 & 0 & 0 & 2 & 0 & 0 \\
\hline Humerus & 2 & 2 & 0 & 16 & 1 & 0 \\
\hline Radius & 1 & 1 & 0 & 9 & 0 & 1 \\
\hline Ulna & 2 & 1 & 0 & 3 & 0 & 0 \\
\hline Femur & 0 & 0 & 0 & 5 & 0 & 1 \\
\hline Tibia & 1 & 1 & 0 & 18 & 1 & 0 \\
\hline Fibula & 0 & 0 & 0 & - & - & - \\
\hline Patella & 0 & 0 & 0 & 3 & 0 & 0 \\
\hline Calcaneus & 1 & 0 & 0 & 5 & 0 & 2 \\
\hline Astragalus & 0 & 0 & 0 & 3 & 0 & 2 \\
\hline Carpal/tarsal & 2 & 0 & 0 & 4 & 0 & 0 \\
\hline Metapodial & 6 & 2 & 0 & 24 & 0 & 1 \\
\hline Phalange & 10 & 5 & 0 & 12 & 0 & 2 \\
\hline Totals & 34 & 16 & 1 & 153 & 2 & 11 \\
\hline
\end{tabular}

Table 5

Total number and percent of cut and burned mammal bones recovered from the Botanical Lens, Paisley Cave 2, Oregon.

\begin{tabular}{llllll}
\hline Animal & Total NISP & Cut & \% cut & Burned & \% burned \\
\hline Pronghorn & 34 & 16 & 47 & 1 & 3 \\
Artiodactyl & 234 & 34 & 15 & 130 & 56 \\
Hare & 153 & 2 & 1 & 11 & 7 \\
Totals & 421 & 52 & 12 & 175 & 42 \\
\hline
\end{tabular}

jackrabbit, fish, and insect remains for the seven subunits of the BL (Table 3), the pronghorn and jackrabbit bones were clustered in just three of these subunits, where $76 \%$ of them were recovered from 


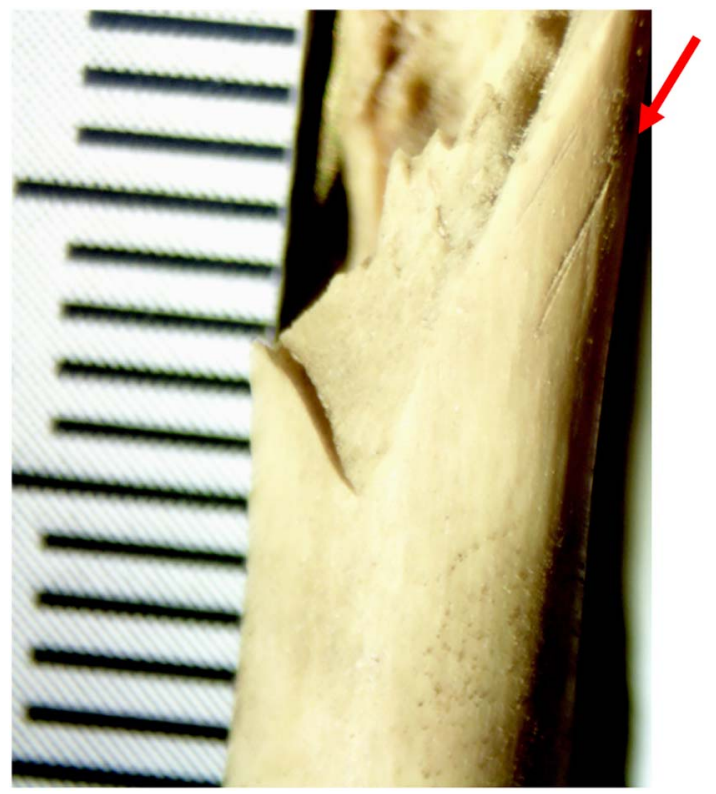

Fig. 5. Stone tool cutmarks on a pronghorn bone fragment from the Botanical Lens.

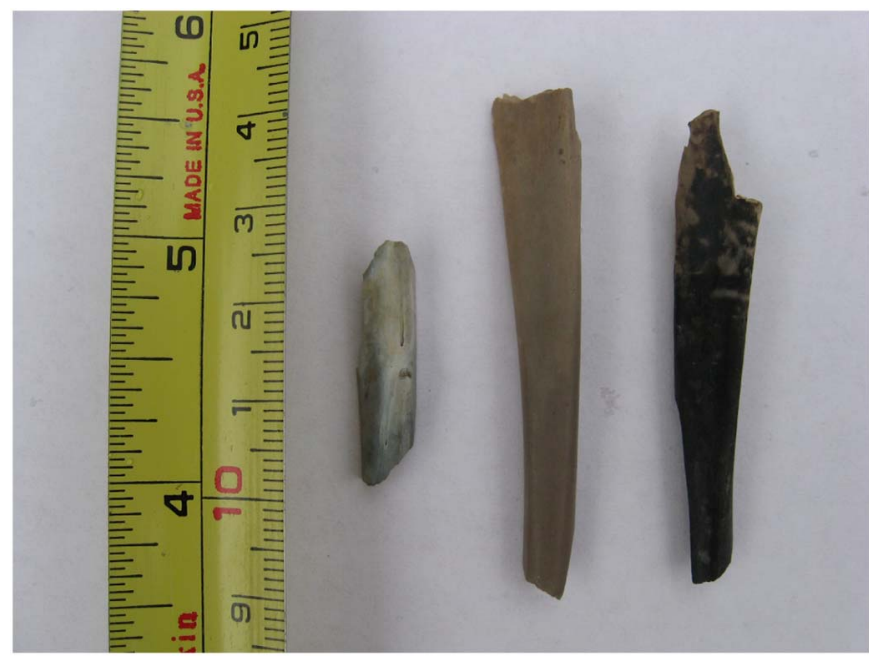

Fig. 6. Burned jackrabbit tibia diaphysis cylinders from the Botanical Lens.

subunits 4A, 7A, and 7C. Almost 54\% of the rabbit (cottontail) bones were found in a single subunit, $7 \mathrm{C}$, that also showed strong evidence for human deposition of pronghorn and jackrabbit bones. The spatial patterning of the fish and insect remains are discussed in more detail in the sections below, but an analysis of the spatial distribution of the mammal and sage grouse bones apart from other evidence suggests human involvement in most of the pronghorn, jackrabbit, cottontail, and sage grouse bones.

\subsection{Botanical Lens fish}

A total of 301 fish remains was documented from the BL sample, including 241 specimens that could be identified finer than the category fish (Table 2). Two fish orders are represented: Cypriniformes (minnows and suckers) dominate, accounting for $89 \%$ of the identified specimens, with the balance (11\%) from Salmoniformes (salmon, trout, and whitefishes). Within Salmoniformes, Oncorhynhus (salmon and trout) alone was identified, based on vertebrae exclusively. The specimens are likely from one of two species of trout known from interior basins of western North America, but as Oncorhynchus vertebrae cannot be identified to species based on morphology, we can only suggest the
Table 6

Body size reconstruction of fish represented in Botanical Lens, Paisley Cave 2.

\begin{tabular}{lllll}
\hline Taxon & Element & $\mathrm{n}$ & Length $(\mathrm{cm})$ & $\begin{array}{l}\text { Size regression } \\
\text { reference }\end{array}$ \\
\hline Siphateles bicolor & Pharyngeal & 1 & 16 (fork) & $\begin{array}{l}\text { Leunda et al., } \\
2013\end{array}$ \\
& Cleithrum & 1 & 12 (fork) & $\begin{array}{l}\text { Leunda et al., } \\
2013 \\
\text { Cyprinidae }\end{array}$ \\
Cyprinidae & Opercle & 1 & 21 (fork) & $\begin{array}{l}\text { Leunda et al., } \\
2013 \\
\text { Rood et al., } 1995\end{array}$ \\
Cypriniformes & Vertebrae & 87 & $\begin{array}{l}12-40 \text { (standard), } \\
\text { mean 24.9, s.d. 6.0 }\end{array}$ & \\
& & & &
\end{tabular}

remains are from trout. All the Cypriniformes remains diagnostic to family or below are from Cyprinidae (minnows), which suggests that all of the materials assigned to Cypriniformes likely are minnows as well. Moreover, the relatively large size of all the Cypriniformes specimens indicate relatively large-bodied minnows. As the minnow Siphateles bicolor (tui chub) alone was identified, this species is likely the main species represented in the BL.

Specimens in the fish sample were primarily vertebrae $(n=140)$ or scales $(n=88)$, although elements from the head, pectoral girdle, and pelvic girdle were also identified. Estimates of minimum number of individuals were five for cypriniforms (five right cleithra dorsal process portions) and one for trout. Remains were distributed unevenly throughout 13 of the 14 excavation subunits. The majority of fish remains $(178 / 301,59 \%)$ were found in the seven core subunits with most abundant mammals and insects (Table 3 ), but very few were recovered in $7 \mathrm{~A}(\mathrm{n}=4)$ and $7 \mathrm{C}(\mathrm{n}=3)$, subunits with a notable concentration of artiodactyl, rabbit, and dermestid beetle remains.

Live length of BL Cypriniformes fishes was estimated using regression models provided by Leunda et al. (2013) for tui chub pharyngeal, cleithrum, and opercle, and the regressions provided by Rood et al. (1995) for minnow/sucker vertebrae (Table 6). These provided size estimates from 12 to $21 \mathrm{~cm}$ (fork length) and $12-40 \mathrm{~cm}$ (standard length). Live length of the BL trout is likely between 30 and $40 \mathrm{~cm}$ by comparison of 11 vertebral widths to trout specimens in the Central Washington University comparative collection.

A key goal was to determine whether the BL fish remains result from human consumption and deposition or another agent (e.g., avian or mammalian predator). Unlike the mammal remains discussed above, the evidence is somewhat equivocal on this point, as is discussed in the remainder of this section. Aspects of the BL clearly indicate human construction and use; and the fish documented in the BL - trout and minnows, including tui chub - are well-known food fishes for indigenous people of the Great Basin based on ethnographic and archaeological records (Butler, 1996; Fowler, 1986; Greenspan, 1990; Raymond and Sobel, 1990). Thus, humans are certainly a plausible source for the BL fish remains. However, other organisms also used the rockshelter periodically and could have deposited fish remains. For example, in Homestead Cave of the eastern Great Basin, Broughton et al. (2006) have demonstrated that owls were the source of the fish fauna recovered there (see also Smith, 1985, Butler and Schroeder, 1998 for other examples).

The main challenge in distinguishing human vs. another agent of deposition is equifinality - that two or more agents could leave a similar trace (e.g., Lyman, 1994). For example, burning is often linked to humans, given humans are a primary source of fire (but see Grayson, 1988), but bones originally deposited by raptors or coyotes could later be incorporated into a fire hearth and then burned. Evidence of digestive erosion and chewing could reflect human consumption, since people are known to eat and consume fish, and produce coprolites (e.g., Follett, 1967; Napton, 1997), but other organisms of course also eat fish as well, and leave similar markings on bones (e.g. Butler and Schroeder, 1998). 
With these difficulties in mind, we attempted to identify the main agent(s) responsible for the BL fish record, examining remains for attributes shown to be useful for distinguishing taphonomic origins: burning that could be linked to human-caused fires; and edge rounding and deformation that can be linked to consumption and digestion (Butler and Schroeder, 1998). We also used reconstructed fish body size to suggest whether fish may have been consumed by human or other predators. We examined all the fish remains for evidence of cutmarks that might indicate butchering or food processing. We studied the spatial distribution of scales, with the expectation that if scales were removed before human consumption, they would be clustered in articulated sheets.

Only two bone specimens from Cave 2 were burned (one blackened trout vertebra and one calcined minnow/sucker vertebra, $0.7 \%$ of fish remains). While it is likely that the burning itself was caused by humans, since only two specimens show this alteration, origins for the bulk of the collection are still obscure. This low proportion of burning is not unexpected for fish remains, however, at least in Great Basin sites. For example, only $1.3 \%$ of 9010 NISP cypriniform remains from a Stillwater Marsh site (26CH1062) were burned (Butler, 1996:707).

None of the remains have cutmarks, although cutmarks may not preserve well in archaeological fish assemblages (Willis and Boehm, 2014). Thus, as with burning, the absence of evidence shouldn't be taken as evidence for a non-human origin. Fish scales were recovered undamaged and disaggregated (none were found adhering to each other), rather than being recovered damaged and/or in articulated sheets as might be expected from scale removal before consumption.

A large proportion of the remains show evidence for consumption and partial digestion. Ninety-one (43\%) of the 213 fish remains excluding scales exhibited edge rounding like that observed in tui chub bones experimentally digested by humans and coyotes (Butler and Schroeder, 1998). All taxa exhibited this digestion damage, including 5 Oncorhynchus sp., 62 Order Cypriniformes, 16 Family Cyprinidae, 3 Siphateles bicolor, and 5 unidentified fish. Three trout vertebrae exhibited signs of deformation that Wheeler and Jones (1989:69) suggest may result from chewing damage. Examples of bones with digestive damage and deformation are provided in Fig. 7.

The high proportion of apparent digestive corrosion in the fish assemblage could be taken as evidence for both non-human and human predators, given that similar modification has been documented on experimentally produced assemblages by both kinds of agents. However, the Paisley Caves have provided human coprolites (Gilbert
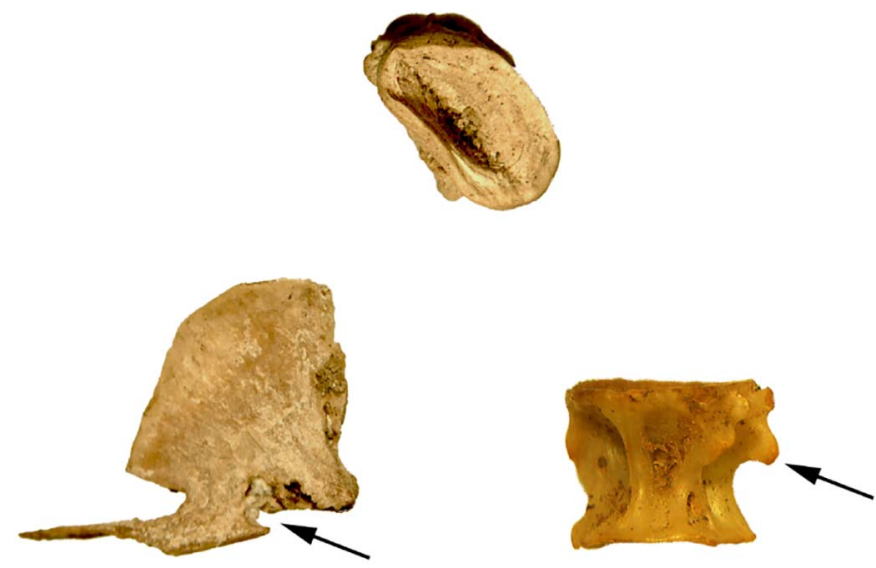

$2 \mathrm{~mm}$

Fig. 7. Examples of BL modified fish bones. At top is a crushed trout vertebra (dorsal surface at top) that appears to have deformed from chewing. At left is a minnow right quadrate (dorsal side at top) with edge dissolution and rounding at arrow. At right is a minnow/sucker vertebra (anterior surface at top) with extensive edge rounding, especially at arrow. et al., 2008), and we know from other Great Basin human coprolites and boli that people ingested fish, including bones (e.g., Eiselt, 1997; Follett, 1967; Rhode, 2003), so it is possible that all this digestive damage is from human consumption of the fish bones. This interpretation is supported by the fact that human coprolites and boli from Hidden, Spirit, and Lovelock caves, like the Paisley Cave fish assemblage, are dominated by minnow remains and include fish scales and small numbers of burned bones (Butler and Schroeder, 1998; Eiselt, 1997; Follett, 1967; Rhode, 2003). The BL fish bones and scales could in part represent the disaggregated remains of human coprolites as Smith (1985) has suggested for some of the Hidden Cave fish assemblage.

On the other hand, the fish represented in the BL are larger than those from Great Basin human coprolites where body size can be estimated, which suggests the BL remains have a different taphonomic history. The BL cypriniform remains, with estimated lengths $12-40 \mathrm{~cm}$ (mean 25) are larger than tui chub recovered in coprolites and stored as dried food in other Great Basin cave sites, which range from 4 to $14 \mathrm{~cm}$ $(\mathrm{n}=398)$ for the former (Butler and Schroeder, 1998; Follett, 1967), and 5-22 cm $(\mathrm{n}=1151)$ for the latter (Raymond and Sobel, 1990:Table 2). Tui chub remains from modern barn owl pellets collected by Broughton et al. (2006) are similarly smaller than the BL sample, with estimated lengths $9-17 \mathrm{~cm}(\mathrm{n}=46)$.

In sum, the evidence for an anthropogenic origin of the BL fish assemblage based on taphonomic criteria is ambiguous. Definitive evidence such as butchery cut marks on bones or scales was not documented. Few bones were burned, although this low proportion of burning is not unexpected for fish remains. The vertebrae with possible chewing damage are also intriguing, but this damage is not a definitive anthropogenic trait. Perhaps bones and scales resulting from small fish were eaten whole (at least the heads), and bones from larger fish treated differently, as is suggested for midden deposits at Hidden and Lovelock Caves (Follett, 1967; Smith, 1985). The question remains: which agents are responsible for the digestive erosion seen on $43 \%$ of the fish specimens? The scarcity of carnivore or raptor damage on the bird and mammal remains is striking, and provides a basis for arguing the digestive erosion on the fish remains reflects human consumption. If evidence for carnivore or raptor activity in the BL was prominent, we would have little basis for assessing whether the fish remains reflect human or nonhuman consumption. However, the almost complete lack of damage from carnivores or raptors in the pronghorn, rabbit, and grouse specimens suggests nonhuman predators and scavengers played a limited role in BL faunal deposition. Thus, based on the larger faunal context for the BL, we argue that humans likely contributed to the digestive erosion evident on the fish remains. We suggest that at least the digested BL fish remains, and perhaps the other fish as well, reflect human use of fish during occupation of the BL.

\subsection{Botanical Lens arachnids and insects}

The remains of 1152 insect parts, representing a minimum of 397 individuals, were recovered from the BL (Tables 1 and 2). It should be noted that insect remains were not collected in all the excavation units. Units $3 \mathrm{~A}$ and $3 \mathrm{~B}$ were excavated in 2002 and insect remains were not regularly collected that year; units $4 \mathrm{D}$ and $6 \mathrm{C}$ hit bedrock before the $\mathrm{BL}$ strats; and insect remains were not collected from unit 7B, though the reasoning for this is not known.

All the individual insects were not deposited at the site as a direct result of human activity; insects deposited by noncultural processes have been categorized as "background fauna" here (Kenward, 1975). For this assemblage, these would include the Arachnida, Hemiptera, Lepidoptera, Hymenoptera, and some of the Coleoptera - specifically, the Carabidae and Tenebrionidae. The discussion below will focus primarily on taxa most likely linked to human activity, which include the Jerusalem and Mormon crickets (Orthoptera) as a possible food source; as well as beetles (Coleoptera: Dermestidae, Histeridae) and the flies (Diptera) that are attracted to carrion and were probably attracted 
to the butchered pieces of pronghorn and jackrabbit hide, hair, bones, and internal body parts left behind on and near the BL feature.

The Orthoptera consists primarily of Jerusalem crickets (Stenopelmatis sp.), Mormon crickets (Anabrus simplex), and an additional unidentified individual represented by an abdominal and cranial fragment that matched neither. Jerusalem crickets are represented solely by mandibles (22 right, 27 left) and several leg segments, a possible indication that these crickets were consumed. Three of the left mandibles appear to have been charred. Mormon crickets, on the other hand, overshadow the Jerusalem crickets in terms of the number of skeletal elements, but represent approximately one-third of all Orthoptera individuals in this assemblage. This is because several individuals are largely whole, or possess enough abdominal and thoracic elements such that not all crickets deposited in the cave were eaten by humans.

Orthoptera consumption in the Great Basin and nearby regions is reflected in the archaeological record primarily by the remains of grasshoppers (Drover, 1979; Hubbell, 1942; Jones, 1948; Madsen and Kirkman, 1988; Madsen and Schmitt, 1998; Orr, 1952; Stiger, 1977) and Mormon crickets (Frison and Huseas, 1968; Frison, 1971), though other Orthoptera remains have also been recovered (Hockett, 2015). The ethnographic record is even more plentiful (Bancroft, 1889; Clark, 1904; Coville, 1897; Douglas, 1959; Egan, 1917; Essig, 1934; Fowler and Fowler, 1971; Holt, 1946; Leechman, 1944; Mooney, 1890; Parkman, 1872; Riddell, 1978; Sapir, 1907, 1909; Skinner, 1910; Wakeland, 1959). Yet the majority of Orthoptera remains in the BL units at Paisley Caves are the remains of the Jerusalem cricket, Stenopelmatus sp. (Adams, 2013; Adams, 2014), which has not previously been recorded in Great Basin archaeological contexts. Furthermore, the nature of the remains is consistent with the notion that these insects were consumed by the occupants of Paisley Cave 2. As noted above, all the Stenopelmatus remains consist of either mandibles or leg segments (Figs. 8 and 9). Ethnographic accounts of Orthoptera-eating people in the Great Basin indicate that, regardless of whether they were cooked or eaten raw, often the only preparation consisted of pulling off the legs and the head (Mooney, 1890; Wakeland, 1959). This would allow the eater to avoid damaging one's teeth on the hard mandibles; the rough legs would have been removed because, as one account noted, "they might have a tendency to tickle one's throat" (Mooney, 1890:260). In addition, the barbs protruding from the hind legs of grasshoppers and crickets are known to stick to a human's esophagus if swallowed, becoming lodged and, in some cases, tearing and damaging the esophagus (Taylor, 1975). The legs of Stenopelmatus are particularly spiny, so this seems a very likely scenario. As a result, those elements not consumed would be expected to be found in the archaeological

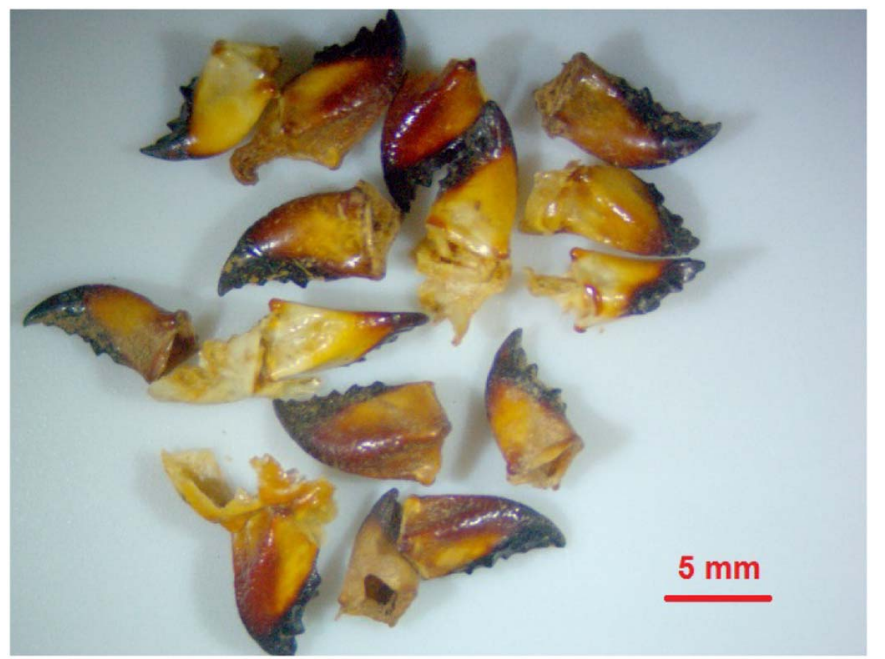

Fig. 8. Jerusalem cricket mandibles from the Botanical Lens.

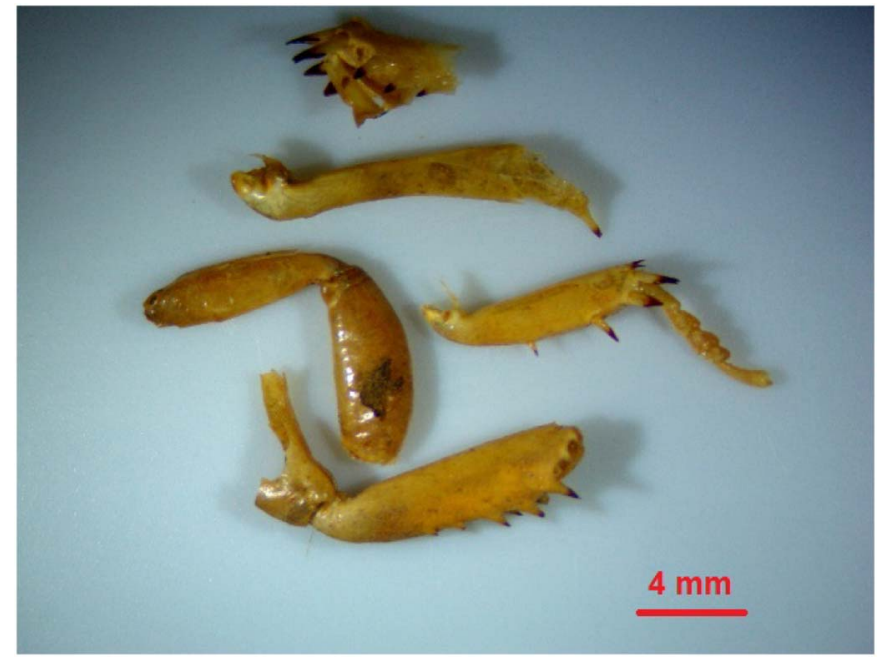

Fig. 9. Jerusalem cricket legs from the Botanical Lens.

record. Removal of the hind legs of katydids (Capnobotes occidentalis) prior to consumption has been documented during the Younger Dryas at Bonneville Estates Rockshelter (Hockett, 2015).

Though the Anabrus simplex elements are more plentiful, they represent fewer individuals (approximately one-half) of the Stenopelmatus individuals. Some of the remains consist solely of legs and mandibles, like Stenopelmatus, and suggest that they were processed and consumed by humans. Other A. simplex specimens are largely whole and may have died with no human intervention. The lower MNI count for A. simplex vs. Stenopelmatus could be explained in a number of ways. First, Jerusalem crickets could simply have been more abundant in the area than Mormon crickets. An examination of the insect remains from Cave 2 spanning over 7000 years - including those from this assemblage - yielded 243 Jerusalem crickets and 26 Mormon crickets, a 9:1 ratio (Adams, 2013; Adams, 2014). Second, Mormon crickets exhibit two distinct phases. Solitary individuals are smaller, cryptically colored and occur in low-density $\left(<\right.$ four individuals $/ \mathrm{m}^{2}$ ) populations; gregarious individuals are larger, darker, and occur in high-density (up to 100 individuals $/ \mathrm{m}^{2}$ ) populations, travelling across the landscape in bands (Gwynne, 2001). Large masses of insects generally attract predators, but the diets of the gregarious crickets consist largely of sagebrush (Artemesia spp.), the foliage of which contain toxins that make them distasteful to predators (Gwynne, 2001; MacVean, 1990; Redak et al., 1992). Sagebrush was present in varying quantities at the Paisley Caves site throughout the late Pleistocene through the Holocene (Saban, 2015). Solitary populations, on the other hand, consume very little sagebrush, and are very palatable to humans and other predators (Hansen and Ueckert, 1970; Ueckert and Hansen, 1970). Thus, the whole Mormon crickets recovered from Cave 2 may be those of the high-density aggregations and show no evidence of being consumed because of their distastefulness. Finally, a third explanation may have to do with locomotion. Although both Jerusalem crickets and Mormon crickets possess large hind legs, only the Mormon crickets generally use them for escape. Generally, both groups crawl, but when escaping from predators, Mormon crickets will jump when disturbed; Jerusalem crickets can jump to escape, but have limited directional control. Instead, when cornered, Jerusalem crickets will roll onto their backs, with their mandibles open and their spiny hind legs poised to kick (Weissman, 2001). The possibility exists, therefore, that Jerusalem cricket remains are found in higher numbers at the site over Mormon crickets simply because they may be easier to catch.

The Coleoptera pertinent to this study are the clown beetles (Histeridae) and the hide beetles (Dermestidae). A single clown beetle, Saprinus oregonensis, was recovered from subunit 6A. From the Greek word sapros, meaning "rotten," Saprinus is associated with dung and 
carrion because it feeds on the soft-bodied fly larvae that are attracted to such environments (Kovarik and Caterino, 2000). Saprinus oregonensis has often been collected in the Pacific Northwest among "evilsmelling flowers" (Hatch, 1961:260). Though the specimen from Cave 2 could have been feeding on coprophagous flies, its presence at a butchering site should not be discounted.

Dermestid beetle remains from Cave 2 were recovered solely from subunit 7C, the same one meter $\times$ one meter subunit that contained a disproportionate percentage of human-butchered pronghorn and jackrabbit remains, and $>50 \%$ of cottontail remains recovered from the $\mathrm{BL}$ feature. The larvae of dermestid beetles feed on the carrion itself, as the flesh and other body parts dry during decomposition. The remains collected are represented by the larval exuviae - the exoskeleton that is shed when the larva is growing bigger and molting. Though the larvae go through several instars before becoming adults, and thus the number of exuviae remains recovered does not equal the number of individual larvae, their presence suggests a significant amount of carrion present at subunit 7C. The larval exuviae were not distinct enough to be able to classify them any finer than a family-level identification.

Of the 1152 insect remains recovered, 52\% were the remains of flies (Order Diptera), and $84 \%$ of those were from the family Calliphoridae (blow flies). The 509 remains of calliphorids represent 216 individuals across the eight subunits in which insect remains were collected. Almost all the remains are fragments of puparia, the cocoons formed when the larvae pupate into adults. In several instances, an undeveloped fly was still inside the puparium, but it was not developed enough for a genus- or species-level identification. Blow flies are scavengers and are attracted to carrion, often used in forensic contexts as an indicator of a corpse's time of death. Their presence in such large numbers in these subunits, like the dermestid and histerid beetles, are strong indicators of butchery and decomposition of a carcass such as the pronghorn carcass described above.

Eight of the fly remains, representing two individuals - one from subunit $6 \mathrm{~A}$ and one from $6 \mathrm{~B}$ - are puparia of the bot fly (Diptera: Oestridae). Unlike the calliphorids, the texture of the puparia is distinctive enough for a genus-level identification. Adult bot flies do not feed, but the larvae are obligate endoparasites of mammals. Both specimens from Cave 2 are from the genus Cuterebra, a New World parasite of rodents and lagomorphs. The larvae enter the host subcutaneously and feed on the host through its larval stages. Before developing into adults, the larvae emerge and drop to the ground, pupating in the soil (Wood, 1987). Though they might be classified as background fauna, they are also indicators of the presence of rodents and lagomorphs, the latter of which were butchered at the site and discarded as part of the BL mammalian fauna. The possibility also exists that even Cuterebra larvae were consumed as food (Skinner, 1910).

The spatial distribution of the insects that indicate human activity, either through collection and processing (Jerusalem crickets and Mormon crickets) or because of hunter-gatherers leaving behind pieces of rotted flesh (dermestid beetles and blow flies) was highly patterned, as indicated above. A total of $94 \%$ of the Mormon crickets were found in a single subunit, $6 \mathrm{~B}$, and almost $75 \%$ of the Jerusalem crickets came from only two subunits, 6A and 6B. All the dermestid beetles (100\%) were recovered from subunit $7 \mathrm{C}$. A total of $81 \%$ of the blow flies were found in three subunits: $6 \mathrm{~A}, 6 \mathrm{~B}$, and $7 \mathrm{C}$.

\section{Discussion and conclusion}

As discussed above, based on the current evidence, some portion of the $\mathrm{BL}$ faunal remains is clearly anthropogenic, some is more ambiguous, and some is likely not the result of human subsistence. Our focus here was on those faunal remains that clearly were the result of human activities or may have resulted from human activities and were therefore worthy of further taphonomic analysis. The most unambiguously anthropogenic are remains of a single pronghorn carcass that was butchered with stone tools, cooked, and marrow removed from the long bones, as well as the remains of seven jackrabbit carcasses. Apparently uneaten portions of pronghorn and jackrabbit hide, hair, and bones with flesh still adhering to the bones were deposited on the BL feature, which attracted beetles and flies. Nearly one-third (32\%) of all the combined artiodactyl, jackrabbit, dermestid beetle, and blow fly remains were found within a single one meter $\times$ one meter subunit (7C). Additional evidence includes butchery cut marks on both pronghorn and jackrabbit bones, and the presence of sections of cut pronghorn hair. The exoskeletons of the dermestid beetles and the cocoons of blow flies remained behind to be covered, along with the BL feature and the mammalian remains, by the Upper Mud Lens and thus preserved. Further corroborating evidence for cultural origin of the fauna from the suite of caves that make up the Paisley Caves includes a small artiodactyl (cf. pronghorn) long bone with stone tool cutmarks recovered from Cave 1 that was directly dated at 11,675-12,015 cal. yr BP $\left(10,180 \pm 60{ }^{14} \mathrm{C}\right.$ yr BP $)$ - the same age as the BL.

Crickets, both Jerusalem and Mormon, were likely collected near the cave and processed for consumption by removing the heads and legs, both of which are problematic for human consumption. The fish remains are more ambiguous but may well be subsistence residue as well. Taphonomic evidence for gastric digestion suggests humans and nonhuman predators (coyotes and/or owls) could have deposited the fish remains. Human deposition of at least some of the fish remains may be shown by a general lack of evidence for other coyote and/or owldeposited bones in the seven subunits displayed in Table 3, as well as a strong human presence in the deposition of the mammal bones among which the fish remains were recovered. This interpretation is equally valid for the cottontail and sage grouse remains.

The relatively diverse suite of animal remains exploited during the Younger Dryas in this portion of the northwestern Great Basin is commensurate with other Late Pleistocene occupations in the western and eastern Great Basin subregions. During the Younger Dryas, huntergatherers at Bonneville Estates Rockshelter along the western margins of Lake Bonneville also exploited artiodactyls (pronghorn, mountain sheep, and deer), jackrabbits, and insects (katydids). At Bonneville Estates, however, sage grouse were also a common prey item (Hockett, 2007, 2015). The sage grouse remains at Paisley Cave 2 are ambiguous concerning their mode of deposition, but similar to the fish remains, their spatial distribution within the BL may indicate some human involvement as 18 of 26 (69\%) sage grouse bones were recovered from within the seven core BL subunits that show particularly strong evidence for human deposition of bones. While postdating the Younger Dryas, the Early Holocene-aged paleofeces extracted from the Spirit Cave mummy abdominal cavity from western Nevada contained the remains of fish (Eiselt, 1997). And recently, burned duck (Anas spp.) bones have been recovered from late Pleistocene/early Holocene cultural deposits at the Old River Bed sites located east of Bonneville Estates Rockshelter (Duke et al., 2016).

Overall, the Paisley Cave 2 BL feature adds significant information to otherwise scant direct evidence for late Pleistocene subsistence activities in the Great Basin. The evidence that is accumulating suggests a wide diversity of animal diet at this time as hunter-gatherers exploited both lowland marshes and upland spring settings, in the process consuming artiodactyls, jackrabbits, sage grouse, fish, waterfowl, and insects.

\section{Acknowledgments}

The Lakeview District Bureau of Land Management office is the research partner of the University of Oregon, providing funding to the Paisley Project and overseeing the management of the site. William Cannon, Lakeview District BLM archaeologist, in particular, has assisted the research at the Paisley Caves. Funding has been provided by the BLM (Lakeview, Reno, Vale offices), National Science Foundation grant \#0924606, Danish National Research Foundation through Eske Willerslev, Director of the Ancient DNA and Evolution Group, Centre 
for GeoGenetics, University of Copenhagen, Denmark, Museum of Natural and Cultural History, University of Oregon through Executive Director, Jon Erlandson, and Arthur Hurley. Bryan Hockett acknowledges the kind assistance of Dennis Jenkins, Pat O'Grady, the University of Oregon, Dave Rhode, and the Desert Research Institute (Reno) during various stages of the analysis of the Paisley Cave fauna. Martin Adams acknowledges Darryl T. Gwenn (University of Toronto) and David B. Weissman (California Academy of Sciences) for discussions I had with them regarding the ecology of Mormon crickets (DTG) and Jerusalum crickets (DBW).

\section{References}

Adams, M.E., 2013. Identification and analysis of insect remains from two excavation units in cave 2, Paisley 5 Mile Point Caves (35LK3400), Lake County, Oregon. In: Report Prepared for the Museum of Natural and Cultural History, University of Oregon. Paleoinsect Research Report, vol. 5 (Portland, Oregon).

Adams, M.E., 2014. Evidence for late-Pleistocene to early-Holocene cricket consumption at the Paisley Caves Site, Lake County, Oregon. In: Paper Presented at the 67th Annual Northwest Anthropological Conference, Bellingham, WA, (March 2014).

Bancroft, H.H., 1889. The Works of Hubert Howe Bancroft - Vol. XXVI: History of Utah, 1540-1886. The History Company, San Francisco.

Broughton, J.M., Cannon, V.I., Arnold, S., Bogiatto, R.J., Dalton, K., 2006. The taphonomy of owl-deposited fish remains and the origin of the Homestead Cave Ichthyofauna. J. Taphonomy 4, 69-95.

Butler, V.L., 1996. Tui chub taphonomy and the importance of marsh resources in the Western Basin of North America. Am. Antiq. 61, 699-717.

Butler, V.L., Schroeder, R.A., 1998. Do digestive processes leave diagnostic traces on fish bones? J. Archaeol. Sci. 25, 957-971.

Casteel, R.W., 1973. The scales of native freshwater fish families of Washington. Northwest Sci. 47, 230-238.

Clark, G., 1904. Indians of the Yosemite Valley and Vicinity: Their History, Customs and Traditions. Self-published, Yosemite Valley, California.

Coville, F.V., 1897. Notes on the plants used by the Klamath Indians of Oregon. In: Contributions From the U.S. National Herbarium. vol. 5. pp. 87-108.

Douglas, D., 1959. Journal Kept by David Douglas During His Travels in North America, 1823-1827. Antiquarian Press, New York.

Drover, C.E., 1979. The Late Prehistoric Human Ecology of the Northern Mojave Sink, San Bernadino County, California. (Unpublished PhD dissertation) University of California, Riverside.

Duke, D., Young, D.C., Rice, S., Hirschi, J., Kitterman, A., 2016. The Wishbone Site: an early Paleoindian waterfowl cooking feature from the Great Salt Lake Desert. In: Paper Presented at the 35th biennial Great Basin Anthropological Conference, Reno, Nevada.

Egan, H.R., 1917. Pioneering the West, 1846-1878: Major Howard Egan's Diary. Howard R. Egan Estate, Richmond, Utah.

Eiselt, B.S., 1997. Fish remains from the Spirit Cave paleofecal material: 9,400 year old evidence for Great Basin utilization of small fishes. In: Nevada Historical Society Quarterly. vol. 40. pp. 117-139.

Essig, E.O., 1934. The value of insects to the California Indians. Sci. Mon. 38, 181-186.

Follett, W.I., 1967. Fish remains from coprolites and midden deposits of Lovelock Cave. Churchill County, Nevada. In: University of California Archaeological Survey Report. vol. 70. pp. 93-116.

Fowler, C.S., 1986. Subsistence. In: d'Azevedo, W.L. (Ed.), Great Basin. Handbook of North American Indians, vol. 11. W.C. Sturtevant, general editor. Smithsonian Institution, Washington, D.C., pp. 64-97.

Fowler, D.D., Fowler, C.S., 1971. Anthropology of the Numa: John Wesley Powell's manuscripts on the Numa Peoples of Western North America, 1868-1880. In: Smithsonian Contributions to Anthropology No. 14, Washington, D.C.

Freidel, D.E., 2001. Pleistocene Lake Chewaucan: Two Short Pieces on Hydrological Connections and Lake-Level-Oscillations. In: Negrini, R., Pezzopane, S., Badger, T. (Eds.), Quaternary Studies near Summer Lake, Oregon: Friends of the Pleistocene Ninth Annual Pacific Northwest Call Field Trip September 28-30, 2001. California State University, Bakersfield (DF1-DF3).

Frison, G.C., 1971. Shoshonean antelope procurement in the Upper Green River Basin, Wyoming. Plains Anthropol. 16, 258-284.

Frison, G.C., Huseas, M., 1968. Leigh Cave, Wyoming, Site 48WA304. In: Wyoming Archaeologist. vol. 11. pp. 20-33.

Gilbert, M.T.P., Jenkins, D.L., Gotherstrom, A., Naveran, N., Sanchez, J.J., Hofreiter, M., Thomsen, P.F., Binladen, J., Higham, T.G.F., Yohe II, R.M., Parr, R., Scott Cummings, L., Willerslev, E., 2008. DNA from Pre-Clovis human coprolites in Oregon, North America. Science 320, 786-789.

Goebel, T., Hockett, B., Adams, K.D., Rhode, D., Graf, K., 2011. Climate, environment, and humans in North America's Great Basin during the Younger Dryas, 12,900-11,600 calendar years ago. Quat. Int. 242, 479-501.

Graf, K.E., 2007. Stratigraphy and chronology of the Pleistocene to Holocene transition at Bonneville Estates Rockshelter, eastern Great Basin. In: Graf, Kelly E., Schmitt, Dave N. (Eds.), Paleoindian or Paleoarchaic? Great Basin Human Ecology at the Pleistocene-Holocene Transition. University of Utah Press, Salt Lake City, pp. 82-104.

Grayson, D.K., 1988. Danger Cave, Last Supper Cave, and Hanging Rockshelter: the faunas. Anthropological papers. In: Part 1. American Museum of Natural History, New York. vol. 66.
Grayson, D.K., 2016. Giant Sloths and Sabre Tooth Cats: Extinct Mammals and the Archaeology of the Ice Age Great Basin. University of Utah Press, Salt Lake City.

Greenspan, R.L., 1990. Prehistoric fishing in the Northern Great Basin. In: Janetski, Joel C., Rhode, David B. (Eds.), Wetland Adaptations in the Great Basin. Occasional Papers No. 1, Museum of Peoples and Cultures, Brigham Young University, Provo, Utahpp. 207-232.

Gwynne, D.T., 2001. Katydids and Bush-Crickets: Reproductive Behavior and Evolution of the Tettigoniidae. Cornell University Press, Ithaca.

Hansen, R.M., Ueckert, D.N., 1970. Dietary similarity of some primary consumers. Ecology 51, 640-648.

Hatch, M.H., 1961. The Beetles of the Pacific Northwest - Part III: Pselaphidae and Diversicornia. University of Washington Press, Seattle.

Hockett, B., 1991. Toward distinguishing human and raptor patterning on leporid bones. Am. Antiq. 56, 667-679.

Hockett, B., 2007. Nutritional ecology of Late Pleistocene to Middle Holocene subsistence in the Great Basin: zooarchaeological evidence from Bonneville Estates Rockshelter. In: Graf, Kelly E., Schmitt, Dave N. (Eds.), Paleoindian or Paleoarchaic? Great Basin Human Ecology at the Pleistocene-Holocene Transition. University of Utah Press, Salt Lake City, pp. 204-230.

Hockett, B., 2015. The zooarchaeology of Bonneville Estates Rockshelter: 13,000 years of Great Basin hunting strategies. J. Archaeol. Sci. Rep. 2, 291-301.

Hockett, B., Jenkins, D.L., 2013. Identifying stone tool cutmarks and the preclovis occupation of the Paisley Caves. Am. Antiq. 78, 762-788.

Holt, C., 1946. Shasta ethnography. In: Anthropological Records. vol. 3. pp. 299-349.

Hubbell, T.H., 1942. Letter report, August 4, 1942. In: Burgh, R.F., Scoggin, C.R. (Eds.), The Archaeology of Castle Park, Dinosaur National Monument. University of Colorado Series in Anthropology No. 2, Boulderpp. 98.

Jenkins, D.L., Connolly, T.J., Aikens, C.M., 2004. Early and Middle Holocene Archaeology in the Northern Great Basin: dynamic natural and cultural ecologies. In: Jenkins, D.L., Connolly, T.J., Aikens, C.M. (Eds.), Early and Middle Holocene Archaeology of the Northern Great Basin. University of Oregon Anthropological Papers, vol. 62. pp. 1-20 (Eugene, Oregon).

Jenkins, D.L., Davis, L.G., Stafford, T.W., Campos, P.F., Hockett, B., Jones, G.T., Cummings, L.S., Yost, C., Connolly, T.J., Yohe II, R., Gibbons, S.C., Raghaven, M., Rasmussen, M., Paijmans, J.L.A., Hofreiter, M., Kemp, B.M., Barta, J.L., Monroe, C., Thomas, M., Gilbert, P., Willerslev, E., 2012. Clovis age Western Stemmed projectile points and human coprolites at the Paisley Caves. Science 337, 223-228.

Jenkins, D.L., Davis, L.G., Stafford Jr., T.W., Campos, P.F., Connolly, T.J., Cummings, L.S., Hofreiter, M., Hockett, B., McDonough, K., Luthe, I., O'Grady, P.W., Reinhard, K.J., Swisher, M.E., White, F., Yates, B., Yohe II, R.M., Yost, C., Willerslev, E., 2013. Geochronology, archaeological context, and DNA at the Paisley Caves. In: Graf, K.E., Ketron, C.V., Waters, M.R. (Eds.), Paleoamerican Odyssey. Center for the Study of First Americans, College Station, Texas, pp. 485-510.

Jenkins, D.L., Davis, L.G., Stafford, T.W., Connolly, Jones, G.T., Rondeau, M., Cummings, L.S., Hockett, B., McDonough, K., O'Grady, P.W., Reinhard, K.J., Swisher, M.E., White, F., Yohe II, R., Yost, C., Willerslev, E., 2016. Younger Dryas archaeology and human experience at the Paisley Caves in the northern Great Basin. In: Kornfeld, Marcel, Huckell, Bruce B. (Eds.), Stones, Bones and Profiles: Exploring Archaeological Context, Early American Hunter-Gatherers, and Bison. University Press of Colorado, Boulder, pp. 127-205.

Jones, V.H., 1948. Prehistoric plant materials from Castle Park. In: Burgh, R.F., Scoggin, C.R. (Eds.), The Archaeology of Castle Park, Dinosaur National Monument. University of Colorado Series in Anthropology No. 2, Boulderpp. 94-99.

Kenward, H.K., 1975. Pitfalls in the environmental interpretation of insect death assemblages. J. Archaeol. Sci. 2, 85-94.

Kovarik, P.W., Caterino, M.S., 2000. Histeridae Gyllenhal, 1808. In: Arnett Jr.R.H., Thomas, M.C. (Eds.), American Beetles, Volume 1 - Archostemata, Myxophaga, Adephega, Polyphaga: Staphyliniformia. CRC Press, Boca Raton, pp. 212-227.

Leechman, D., 1944. Further light on "wooden tubes" from Oregon. Am. Antiq. 9, 451.

Leunda, P.M., Galicia, D., Miranda, R., Madoz, J., Parmenter, S., 2013. Bone-to-body biometric relationships for Owens and Lahontan Tui chubs and their hybrids in California. J. Fish and Wildl. Manag. 4, 326-331.

Lyman, R.L., 1994. Vertebrate taphonomy. In: Cambridge Manuals in Archaeology. Cambridge University Press, Cambridge.

MacVean, C., 1990. Mormon crickets: a brighter side. Rangelands 12, 234-235.

Madsen, D.B., Kirkman, J.E., 1988. Hunting hoppers. Am. Antiq. 53, 593-604.

Madsen, D.B., Schmitt, D.N., 1998. Mass collection and the diet breadth model: a Great Basin example. J. Archaeol. Sci. 25, 445-455.

Mooney, J., 1890. Notes on the Consumnes tribes of California. Am. Anthropol. 3, 259-262.

Napton, L.K., 1997. The Spirit Cave Mummy: Coprolite Investigations. Nev. Hist. Soc. Q. 40, 97-104.

Orr, P.C., 1952. Preliminary excavations of Pershing County caves. In: Nevada State Museum, Department of Anthropology Bulletin No. 1, Carson City.

Parkman, F., 1872. The Oregon Trail. Ginn and Co., Boston.

Payne, S., 1972. Partial recovery and sample bias. In: Higgs, Eric S. (Ed.), Papers in Economic Prehistory. Cambridge University Press, Cambridge, pp. 49-64.

Raymond, A.W., Sobel, E., 1990. The use of Tui chub as food by Indians of the Western Great Basin. J. Calif. Gt. Basin Anthropol. 12, 2-18.

Redak, R.A., Capinera, J.L., Bonham, C.D., 1992. Effects of sagebrush removal and herbivory by Mormon crickets (Orthoptera: Tettigoniidae) on understory plant biomass and cover. Environ. Entomol. 21, 94-102.

Rhode, D., 2003. Coprolites from Hidden Cave, revisited: evidence for site occupation history, diet and sex of occupants. J. Archaeol. Sci. 30, 909-922.

Riddell, F.A., 1978. Honey Lake Paiute ethnography. In: Occasional Papers of the Nevada State Museum No. 3, Carson City. 
Rood, R.J., Butler, V.L., Newman, M., 1995. Archaeofauna. In: McKibbin, Anne (Ed.), The Pescadero Site (48LN2068): Final Report of Excavations, Lincoln County, Wyoming. Metcalf Archaeological Consultantspp. 156-191 (Submitted to Williams Field

Services. Copies available from Metcalf Archaeological Consultants, Eagle, Colorado).

Saban, C.V., 2015. Palynological Perspectives on Younger Dryas to Early Holocene Ecology at Paisley Caves, Oregon. (Unpublished M.A. thesis) Oregon State University, Corvallis.

Sapir, E., 1907. Notes on the Takelma Indians of Southwestern Oregon. Am. Anthropol. 9, $251-275$.

Sapir, E., 1909. Takelma Texts. In: Anthropological Publications of the University of Pennsylvania Museum. vol. 2, no. 1 (Philadelphia).

Skinner, A., 1910. The use of insects and other invertebrates as food by the North American Indians. J. N. Y. Entomol. Soc. 18, 264-267.

Smith, G.R., 1985. Paleontology of hidden cave: fish. In: Thomas, D.H. (Ed.), The Archaeology of Hidden Cave, Nevada. Anthropological Papers No. 61. American Museum of Natural History, New Yorkpp. 171-178.

Stiger, M.A., 1977. Anasazi Diet: The Coprolite Evidence. (Unpublished M.A. thesis) University of Colorado, Boulder.

Taylor, R.L., 1975. Butterflies in My Stomach: Insects in Human Nutrition. Woodbridge
Press Publishing, Anaheim, California.

Ueckert, D.N., Hansen, R.M., 1970. Seasonal dry-weight composition in diets of Mormon crickets. J. Econ. Entomol. 63, 96-98.

Wakeland, C., 1959. Mormon crickets of North America. In: U.S. Department of Agriculture, Agricultural Research Service Technical Bulletin No. 1232, Washington, DC.

Weissman, D.B., 2001. North and Central American Jerusalem crickets (Orthoptera: Stenopelmatidae): taxonomy, distribution, life cycle, ecology and related biology of the American species. In: Field, L.H. (Ed.), The Biology of Wetas, King Crickets and Their Allies, CAB International, New York, pp. 57-72.

Wheeler, A., Jones, A.K.G., 1989. Fishes. In: Cambridge Manuals in Archaeology. Cambridge University Press, Cambridge.

White, T.E., 1953. A method of calculating the dietary percentage of various food animals utilized by aboriginal peoples. Am. Antiq. 18, 396-398.

Willis, L.M., Boehm, A.R., 2014. Fish bones, cut marks, and burial: implications for taphonomy and faunal analysis. J. Archaeol. Sci. 45, 20-25.

Wood, D.M., 1987. Oestridae. In: McAlpine, B.V., Shewell, G.E., Teskey, H.J., Vockroth, J.R., Wood, D.M. (Eds.), Manual of Nearctic Diptera. vol. 2. Biosystematics Research Centre, Ottawa, pp. 1147-1158. 